\title{
КОМПАРАТИВНО ИСТРАЖИВАЮЕ НЕОАВАНГАРДНИХ ПОКРЕТА У ЕВРОПИ И САД
}

Сажетак: Предмет истраживања су неоавангардни покрети у Европи и САД. Циљ истраживања је проналажење сличности и разлика између европске и неоавангарде у САД. Неоавангардом се именује скуп разнородних уметничких подухвата који настају након Другог светског рата. Она настаје на европском тлу као вид разумевања и критике друштва, али се међу неоавангардне уметничке праксе убрајају и уметнички иступи какви се налазе у Северној Америци. Појам се афирмише у Италији шездесетих година, где је и дошло до највећег развоја неоавангарде. Њена усмереност ка социјално-политичком ангажману је заједничка карактеристика овог периода. Особеност свих уметничких подухвата неоавангарде је изражено осећање деперсонализације. Разлике се првенствено уочавају унутар сензибилитета за политику. Код европских неоавангарди може се говорити о упадљивом интересовању за политику. У поређењу са европском, америчка неоавангарда исказује мање амбиције ка политичком ангажману. Рад показује да су и на европску и на неоавангарду у САД утицали супкултурни и контракултурни покрети.

Кључне речи: авангардни покрети, неоавангарда, контракултура, Европа, САД.

\section{Појам неоавангарде: Европска неоавангарда}

Неоавангардом $^{3}$ се именује скуп разнородних уметничких подухвата који настају након Другог светског рата нарочито током 60-их година прошлог века. Ови покрети настају на темељу уметничких авангарди формираних у првим деценијама XX века, доводећи до крајњих граница њене основне естетичке и

\footnotetext{
${ }^{1}$ borisilic1401@gmail.com

2 Чланак представља делимично измењени завршни део докторске дисертације под називом Социолошки аспекти стваралаштва и рецепције на примеру европских неоавангардних уметности: Италија и Франиуска, коју је аутор одбранио на Филозофском факултету у Нишу јуна 2019. године.

${ }^{3}$ Миклош Саболчи наводи да се тај појам први пут појавио у италијанској књижевној критици у оквиру Групе 63 у песничкој збирци I Novissimi. Већ је Едоардо Сангвинети појам неоавангарде користио како би именовао своје експерименте. „Паралелно са овим термином јављају се још и nuova avanguardia y nuovo sperimentalisimo, али око 1965., већ је ушао у општу употребу“ (Саболчи: 1998: 87).
} 
идеолошке постулате. Неоавангарда тако представља она уметничка прегнућа која се естетски одликују стваралачком инвенцијом, а политички, темељитим раскидом са капиталистичким друштвеним поретком и обрасцима мишљења и понашања који га дефинишу. Настају на европском тлу као одређени вид разумевања и критике друштва, али се међу неоавангардне уметничке праксе често убрајају и они уметнички иступи какви се налазе у послератној Северној Америци, као што су поп арт, минималистичка и концептуална уметност. Сам појам се афирмише у Италији раних 60-их година, где је и дошло до највећег развоја неоавангардне уметности.

Теоретичари нису једногласни када је у питању дефиниција неоавангарде. Поред тога што се на формално-садржинске елементе неоавангардних уметничких дела гледа на различите начине, и на њену друштвено-политичку улогу гледа се са различитих, понекад потпуно супротстављених позиција. Заједничко већини теоријских позиција је то да неоавангарда представља уметнички израз настао као последица и критички одговор на социо-културне, техничко-технолошке и политичке процесе XX века. Већина аутора о којима ће бити речи, дефинишући појам неоавангарде, анализе усредсређују на европску неоавангарду.

Хуберт ван ден Берг (van der Bergh) и Валтер Фендерс (Fähnders), полазе од става о мрежи авангардних покрета која се јавља првих деценија XX века, a наставља након Другог светског рата и своје трајање продужава до данашњих дана. Ови аутори посебно апострофирају чињеницу да се у оквиру неоавангардног стваралаштва уметност први пут појављује у облику акција, а не готових уметничких дела (ван ден Берг/Фендерс, 2013: 26).

Акиле Бонито Олива (Bonito Oliva) европске неоавангарде види као израз спајања и снажног набоја историјско-идеолошке свести и поштовања естетичких постулата историјских авангарди. Пример прожимања идеолошке супстанце и естетичких начела виђен је у Бечком акционизму ${ }^{4}$, јер на уметност примењује одређене захтеве акције које се схватају као шок за садашњост историје (Види: Бонито Олива/Карло Арган, 2006: 7-9). Налази истраживања које је аутор спровео и изложио у овом раду у великој мери кореспондирају резултатима до којих је дошао Бонито Олива, поредећи европску и неоавангарду у САД. Он сматра да од средине седамдесетих, а посебно од осамдесетих година XX века, неоавангардну поетику смењује деловање трансавангарде, као вид понирања у шире еклектичке уметничке захвате. Уметник овом еклектицизму наново додаје и класични приступ стваралаштву и индивидуални рад. За разлику од Бонита Оливе, на основу спроведеног истраживања аутор овог рада неоавангарду сагледава као скуп разнородних уметничких тенденција наслоњених на ране авангарде, насталих раних 50-их година, а које махом надахњују настанак постмодернизма на почетку 80-их година прошлог века.

\footnotetext{
${ }^{4}$ О покрету Акциониста читалац се може обавестити у делу Гералда Раунига Art an Revolution: Transversal activism in the Long Twentieth Century. „Art and Revolution 1968“: Viennese Actionism and the Negative Concatenation. pp. 187-203.
} 
Међу теоретичарима који своје опсервације темеље на критици неоавангарде спада Петер Биргер (Bürger). Он заступа став да се деловање неоавангарде заснива на усвајању смисла за који су авангарде веровале да ће допринети негацији уметности. Стога, овај смисао постаје унутрашња естетска процедура прихваћена од институција, па испада да неоавангарда није ништа друго до „препис“ авангардне поетике, која је сада само номинално бунтовничка, а суштински њен израз тржишно прихваћен (Bürger, 2011: 707-709).

Мишко Шуваковић сматра да неоавангарду сачињавају критички и експериментални пројекти трансформације уметности и друштва које повезују различите парадигме уметности удружених у mixed media дефинисању неоавангардних покрета: 1. Оне се појављују као закаснели продужетак „класичних авангарди“. 2. Неоавангарда представља конкретну реализацију утопијских визија и алегорија „класичних авангарди“ које су се могле створити тек у развијенијој индустријској култури након Другог светског рата. 3. Неоавангарда је виђена као аутономна у односу на претходне авангарде и као таква изражава експериментални, критички и ексцесни дух времена позног капитализма, културе хладног рата и постиндустријског друштва. 4. Европска неоавангарда, при чему се мисли на неоконструктивизам, визуелну поезију, флуксус, нови роман, итд., реализује пројекат високе модерности. 5. Англосаксонска неоавангарда (неодада, флуксус, хепенинг, бит поезија, поп арт) исказују се као критика гинбергијанске естетике високог модернизма. 6. Источноевропску неоавангарду чине неодада, визуелна поезија, структуралистичка књижевност, те експериментални андерграунд филмови. Она егзистира посредством идеолошких сукоба соцреалистичке догматске културе, производећи умерену модернистичку уметност, бирократског и технократског слоја и утопијских либералних и анархистичких концепата (Шуваковић, 1995: 90-91).

Неоавангардни уметници су пионири заокрета на језик. За њих језик није само средство комуникације, већ појава посебне врсте, која на веома битан начин у садејству са факторима социјалног окружења одређује свест појединаца и група. Авангардна уметност раног периода се ограђивала од концепта аутономије уметности, али се, упркос том декларативном ставу, њена укупна производња испољавала у форми готових уметничких дела у класичном смислу речи. Неоавангарда, с друге стране, ширећи интелектуалне хоризонте у корпус својих дела убраја и филозофске есеје, перформансе, али и манифестације свакодневног живота који имају мало тога заједничког са стварањем уметничког дела у уобичајеном смислу и тешко да се могу захватити појмовима класичне естетике. Од шездесетих и почетка седамдесетих година минулог века у уметности су све више присутне мултимедијалне инсталације, као могућност еклектичког приступа уметности, али и као идеја о крају уметности, безидејности, непродуктивности и одсуства жеље уметника за стварањем посредством традиционалних уметничких поступака. ${ }^{5}$

\footnotetext{
5 Розалинд Краус говори о потреби авангардних уметника у периоду након Другог светског рата за међусобним повезивањем и стварањем нових уметничких дисциплина, а као пример
} 


\section{Неоавангарда у САД: супкултуре, поп арт и концептуална уметност}

Већина разматрања о културној промени која настаје у САД почетком XX века, почиње од увида у трансформације начина живота током тог века које је изнео Дејвид Рисман (Riesman) у познатој књизи Усамљена гомила (Рисман, Глејзер, Дени, 2006). О супкултурама се обично говори као о ужим друштвеним групама које се према изграђеном аутохтоном систему вредности и створеним значењима разликују у односу на вредности које намеће владајућа култура. Како Никола Божиловић истиче, овде није у питању антагонистички однос, већ је реч о коегзистенцији. Вредности владајуће културе постоје паралелно са вредностима супкултура. Подразумева се да и припадници поткултура усвајају највећи број вредности владајуће културе. Божиловић пре свега има у виду музичке супкултуре којима се и овде бавимо. Верујемо да управо оне долазе у најближи додир и испреплетене су са вредностима неоавангардних уметности. Према његовом мишљењу, поткултуре настају из значења стила, а он се манифестује посредством посебног начина говора, одевања, тетоважа, беџева и сл.

Осим супкултура у друштву се, услед различитих социјалних, политичких и културних процеса, појављују и групе које се директно супротстављају вредностима владајуће културе. Реч је о контракултурама које представљају спонтано настале социјалне групе. Оне имају различиту „генезу и манифестације, али им је заједничка карактеристика принцип генерацијске регрутације учесника и неформалност група, као и масован, али и непосредан аудиторијум“ (Божиловић, 2009: 23). Прва истраживања супкултура у социологији започињу смештањем овог начина груписања младих унутар девијантних група које карактеришу неке од или више таквих удружених појава: крађа, силеџијство, алкохолизам, наркоманија, проституција, итд. Божиловић примећује да оваква тумачења често супкултуре доводе у везу са присуством менталних поремећаја код њених припадника. Он се супротставља овим тумачењима, тврдећи да се супкултуре формирају на основу насталих заједничких и социјално узрокованих потреба за оспоравањем друштвеног система и владајућег начина живота. „Њени припадници залажу се за нов начин живота, нове облике породичног организовања, другачије форме рада и 'некаријеризам'“ (Божиловић, 2009: 2425). Проблем контракултуре на практичном плану се изражава као немогућност да се захвати тоталитет, већ само неки аспекти друштвеног живота. Ограничавајући се на поље духовне културе (поезија, музика, позориште, сликарство, итд.), она не залази дубље у целокупност начина производње друштвеног живота, на стварне социјално-политичке и привредне односе ширег друштва, те на тај начин остаје само идеалистички израз апстрактне тежње за променом (Божиловић, 2009: 26). Аутор и поред овога одаје признање контракултури на изградњи потенцијала за преиспитивањем друштвених токова и амбиција (ма

ове праксе наводи перформанс који комбинује музику Филипа Гласа, плес Лусинде Чајлдс и скулптуре Сола Левита (Види: Krauss, 1979: 60-64). 
колико оне биле идеалистички утемељене) на ангажману и захтевом за радикалном променом постојеће културе.

Разлика између супкултура и контракултура видљива је на примеру филма, рецимо Бунтовник без разлога (1955), и сличних остварења, која су успостављала комуникацију са млађом интелигентном публиком подстичући њен бунтовни сензибилитет, али се она духовно и у пракси свакодневног живота не одриче вредности успостављеног друштвеног система. Образована је авантуристички и привремено, а ограничена на омладински узраст. С друге стране су битници, чији утицај је најснажнији управо пред образовање хипи покрета. Они представљају израз контракултурног груписања који своје вредности директно и бескомпромисно супротставља вредностима друштвеног система.

Није уопште чудно што битнике један број теотеричара третира као контракултурни док их други виде као авангардни покрет. Како бележе Дик Хебдиџ (Hebdige) и садардници, под појмом битници се подразумева група младих интелектуалаца који су тежили живљењу новог начина живота изван устаљених конвенција. Почетак битничког деловања, сматра се, датира од 1944. године, када су се сусрели песник Ален Гинсберг (Ginsberg), писац и сликар Вилијам Бароуз (Burroughs) и писац Џек Керуак (Kerouac). Раних педесетих објављене су књиге које се сматрају кључним за овај покрет. Керуаково дело Град и велеград (1950), као и Гинсбергова збирка песама Урлик и остале песме (1956). „У Њујорку, у његовој боемској четврти, Гринвиџ Вилиџ (Greenwich Village), већ крајем четрдесетих година почела је да се окупља нова генерација младих уметника (...). Вилиџ су насељавали углавном млади неафирмисани уметници, сликари и писци. Када су Вилиџ населили битници дали су целокупном миљеу посебну атмосферу нове боемије“ (Хебдиџ и сарадници, 2002: 23).

Ови аутори сматрају да је појава битника убедљиво најзначајнија културна појава током 50-их година XX века. Кључни елемент који одређује покрет битника је пасивни отпор. „Више него осећање досаде, ова реч (битник, подвукао Б. И.) изражава и осећање злоупотребљених и рањених“. Поезија битника изражава огољеност мисли и душе, ,jедно осећање сведености на саму основу свести“. Бит поезија, по њиховом мишљењу, трага за сопственом аутентичношћу. Поглед на свет битника, по свему судећи, обликовао је егзистенцијализам. Ипак, битник за разлику од егзистенцијалисте није био заокупљен питањем избора, већ он бира беду као властити избор. Током 50-их година минулог века, битници су кренули путем ,добровољног сопственог отуђења од култа породице, новца и свих њихових облика и начина“ (Хебдиџ и сарадници, 2002: 25-26). Неспутана мистична сексуалност, међусобно поверавање уз коришћење марихуане и читање поезије на глас били су важни ритуали битничке контракултуре.

Божиловић истиче да се битници, усвајајући елементе црначке џез и бибап културе „супротстављају вредностима белог, протестантског грађанства оличеног у square-u (малограђанину, некоме ко је ограничен)“ (Божиловић, 2009: 54). Такође се указује на то да битничку културу не треба искључиво везивати за простор Сједињених Америчких Држава. 
Рок музика као духовни носилац супкултурних и контракултурних покрета, која настаје средином и крајем 50-их година и то управо на тлу САД, у склопу бурних промена које се одвијају током шездесетих година прошлог века како у политици и економији, тако и у култури, изнедрила је још један важан покрет омладинске контракултуре - хипи покрет - о чему на социолошком плану сведочи и данас утицајна студија Теодора Рошака (Roszak) Контракултура (1978). Он запажа да савременим друштвом влада технократија, која стреми томе да присвоји утицај у свим аспектима друштвеног живота: сексуалном понашању, одгоју деце, менталном здрављу, рекреацији, итд. Пажња технократа се усмерава на то да све активности у друштву постану „чисто техничким предметом професионалне пажње“ (Рошак, 1978: 16-17). Реч је о режиму експерата и њихових послодаваца. Технократија измиче свим традиционалним политичким категоријама јер не експонира идеолошку суштину. Наглашава се да је овде реч о потпуно новом облику капитализма, који на рачун развоја система контроле који стварају технократске владајуће структуре, потенцијално може занемарити и бригу о профиту, а она би и у том случају, вели Рошак, остала моћна (Рошак, 1978: 25).

Друштвене групе које се овако структурисаном систему владавине технократије супротстављају могу се назвати побуњеном омладином или, како Рошак каже, „контракултуром“. Настајањем контракултуре, чији су носиоци рок музика и студентска омладина, повезано је, поред недвосмисленог противљења технократији, и са оним захтевима који се тичу питања о човеку као личности, повратку хуманости и одбацивању идеологије, а посебно технократских начела, што контракултуру чини више културном него политичком појавом.

Она за свој предмет, вели Рошак, има политику, промишља је, а затим одбацује у име духовних вредности на којима се сама заснива. Одећа коју носе је неуредна, а музика, на пример Битлса (Beatles) психоделична, неконвенционална. Кључно у Рошаковом гледишту, које представља суптилну анализу општих друштвених кретања унутар и око контракултуре је то да он ову појаву види као један од начина културног експериментисања, што је чини блиским основним постулатима неоавангардних пракси. Хипи покрет адекватно описују речи Рошакове студије: борба против технократије, слушање рок музике и противљење рату у Вијетнаму. Овде такође спада ширење опсега знања ван граница које нуди систем формалног образовања, као и истицање љубави, слободе и мира као основних вредности на којима би друштво требало да почива. Као и битничка, тако је и хипи контракултура, према Хебдиџу и сарадницима, у своме друштвеном средишту имала литерарно-уметничку интелигенцију. „Око овог језгра окупила се аристократија рок музичара и велики број следбеника који су прихватили један бунтовнички стил живота““ (Хебдиџ и сарадници: 2002: 60). Ову супкултуру, сматрају аутори, карактеришу: пасивни отпор, покретљивост, одрицање, експресивност, субјективност и индивидуализам. Важно је истаћи да су друштвене везе између неоавангардних уметника, рок музичара, студентског покрета и шире публике били важан фактор у изградњи епохалне свести 
која је карактерисала период од раних 50-их до касних 70-их година XX века. У књизи Историја моде (1995), Елизабет Вилсон (Wilson) скреће пажњу на то да је унутар хипијевске естетике посматране кроз стил одевања био присутан и благи утицај кича (Вилсон, 1995: 92).

Шездесете године, како примећује Франсоа Кисе (Cusset), представљају кризу социолошког функционализма и истраживања тржишта, који су оптуживани да друштво своде на прост израз бројчаних показатеља и увећавају друштвене неједнакости. У први план избија и криза легализма, а маршеви за грађанска права захватају све шире скупине људи. По среди је, оцењује Кисе, слично Рошаку, криза технократског легитимитета. На ово се надовезује, како се изражава, криза административног ума, кога потреса корупција све бројније менаџерске структуре. Он бележи да се студентски покрет од почетка 50-их па до краја 70-их, развио „од организоване политичке опције до спонтаног модуса понашања чији су циљеви изнад свега били егзистенцијални“ (Кисе, 2015: 73-74). За Кисеа се одраз тих промена које се одвијају након Другог светског рата може пронаћи у песмама Боба Дилана (Dylan). У контексту рецепције француске теорије у САД, он износи тврдњу да је метаморфоза студентске побуне која је укроћена бруталном репресијом током седамдесетих један од најважнијих фактора за пријем и скретање пажње на француску теорију (постструктурализам). Од овог момента пажња интелектуалне јавности и младих активиста се преусмерава са борби на дискурсе, тј. њихов значај за целокупан систем идеја антикапиталистичке оријентације. Борбе од тада постају секундарни начин побуне. Од огромног значаја за целокупан хипи покрет и студентску побуну имала су дела, поетске и филозофске опсервације Пола Гудмана (Goodman). Када је битничка књижевност и пратећи бунт спласнуо 60-е године, према Кисеу, изумевају културну побуну „и фаворизују, нарочито у Њујорку и Сан Франциску, плетење густе контракултурне мреже“ (Кисе, 2015: 87). Тада настаје приличан број часописа који се одваја од омладинске супкултуре, заснивајући свој рад на анархистичким начелима. Кисе вели да постструктурализам образовање своје идеолошке позиције добрим делом дугује интересовањима за америчку контракултуру. Жил Делез (Deleuze), Феликс Гатари (Guattari), и Мишел Фуко (Foucault), од 60-их до почетка 80-их година прошлог века исказују дивљење Гинсбергу, Бароузу, музици Џона Кејџа (Cage). Негују блиске односе са рок и панк бендовима од Дилана и Џоан Баез (Baez), до носилаца новог рок звука у САД, панка и новог таласа, Patti Smith i B52's (Кисе, 2015: 90). Тако се, могло би се рећи, неоавангардне праксе добрим делом наслањају на супкултурне и контракултурне видове комуникације. Пријем француске теорије се у САД појавио истовремено у облику филозофског знања, авангардног деловања и контракултурног ангажмана. Ову праксу настављају поп арт и концептуална уметност али ове уметничке праксе одлазе и корак даље.

Иако усмерен ка видно изокренутом естетском промишљању стварности, тј. њеном до крајности извештаченом приказу са елементима кича који се појављује у функцији кемпа, поп арт виђен кроз призму Ворхоловог (Warhol) стваралаштва, заправо представља манифестацију колективне уметничке акције. За 
њега „савремена уметност није дело усамљеног генија, већ нека врста катализатора различитих спољашњих утицаја“ (Хонеф, 2008: 82). Поред усмерености на представљање комуникацијског и предметног елемента масовне културе, донекле неутралне вокације, поп арт и посебно Ворхол, приказују њено наличје уз критички призвук. Дела у којима се на ироничан начин славе производи масовне културе и амерички начин живота, представљају Ворхолови радови 80 новчаница од 2 долара предюа и задња страна, или Конзерва супе Кембел, док би се критичка интонација Ворхоловог стваралаштва могла представити делом 129 погинуло у авионској несрећи. Из претходних навода јасно је и зашто је уметнички правац добио назив поп арт. Он је усмерен на истицање главних токова масовне културе као основних образаца живота човека модерног друштва. Медији и артикли масовне производње бивају кључни садржински елементи дела поп арта. Енди Ворхол је, поред овога, стварао чврсте везе са скупинама оних рок музичара који су били, како би то Божиловић рекао, „изван главног тока“ популарне музике, при чему је његов рад повезан са групом Велвет Андерграунд (Velvet Underground) од суштинског значаја. Енди Ворхол и Велвет Андерграунд су посредством музике и свеукупног естетског израза групе били пресудно важни за конституисање стила британског глем рока, а посредством овога и панка. С друге стране, Ворхолови радови у пољу ликовних уметности и филма долазе у близак додир са начелима постмодернизма.

Другачије је виђење концептуалних уметника. За ствараоце поп арта предмет се не доводи у питање. Он је недвосмислено централни моменат дела. Иако је реципијенту остављен избор начина интерпретације, предмет је присутан на реалистички начин.

Концептуална уметност настаје крајем 60-их година, а најчешће се представља посредством дела Џозефа Кошута (Kosuth). Инсистира се, пре свега, на одсуству предмета уметничког дела. Овај уметнички израз настаје на темељу психоанализе, филозофије Лудвига Витгенштајна (Wittgenstein), Дишановог (Duchamp) ready made-a, а нешто касније и разних облика марксизма. У средишту стваралаштва је виђење уметности као дематеријализоване уметникове креације. Тачније, суштина стваралаштва није у делу, већ у процесу стварања који је произведен и обликован путем језика.

Ствараоци овог опредељења износе мисао да је уметност оно што се језиком означава уметношћу. Тиме уметник истовремено постаје и критичар, уметник и кустос. На социолошком плану ово значи радикалну промену перцепције друштвених улога, где се три одвојене улоге према схватању традиционалне уметности у концептуализму трансформишу у јединствену улогу концептуалног уметника. И још више од тога, он постаје теоретичар друштва и културе са специјализацијом у области критичког разумевања уметности. У том смислу, према Николи Дедићу, концептуална уметност је таква појава „коју је више немогуће описати унутар категорија стила и медија, већ искључиво на основу начина на који преиспитује статус уметности као друштвене институције“ (Дедић, 2009: 159). Посредством концептуалне уметности стваралац долази у позицију истраживача, активисте, теоретичара и уметника у исто време. Умет- 
ничко дело схваћено као дематеријализовано, формално или само рудиментарно, постаје супстрат на коме се издижу теоријске конструкције о конкретном уметничком делу, институцији уметности и ширем социо-културном контексту његовог настанка. Дело се изједначава са мишљу и језиком.

Важност и вредност стваралачко-рецептивних релација и конкретног дела које је узето за повод ове комуникације, истичу предност језичког и ширег друштвеног и културног контекста на рачун уметничког дела. Основна тежња концептуализма је одрицање од строгих дефиниција модернистичког виђења уметности, видљиво у делу Клемента Гринберга (Greenberg). Дедић наглашава и то да се концептуалне уметничке праксе, иако настају истовремено са неоавангардним покретима, од њих разликују по негирању утопијске заснованости уметности, тј. њеног идеолошког усмерења. Ово је могуће ако се има у виду да је концептуална уметност дематеријализована уметност (Дедић, 2009: 165). Она се није конституисала по неком унапред створеном кључу за пројектовање политичких доктрина, већ као покушај реконструкције друштвеног света и улоге институције уметности у њему.

Овде се изражава гледиште да је концептуална уметност чврстим нитима повезана са авангардним покретима након Другог светског рата и то путем праксе темељног критичког преиспитивања институције уметности. У обема су уметничка идеја и контекст у коме се она јавља однели победу над уметничким предметом и друштвеном ознаком уметника. Управо из тих уметничких оквира се развија неоконцептуална уметност виђена кроз радове Барбаре Кругер (Kruger). Овај вид уметничког деловања заснива се „на примени концептуалних метода на истраживање друштвених пракси производње значења, облика приказивања у популарној култури и механизма производње и потрошње у постмодерном друштву“ (Шуваковић, 1995: 66). Концептуална уметност, због своје оријентисаности на језик и интерпретативне активности као носиоца модерне уметности, те на стваралачко-рецептивни контекст, као друштвена појава исказује низ сличности са европском неоавангардом.

\section{Компаративна анализа европских и америчких неоавангардних уметности}

На општем плану може се уочити да се модерна уметност у другој половини XX века, како у европским тако и ваневропским земљама, надограђује на искуства авангардних покрета с почетка века. Одрицање од традиционалних уметничких поступака је идеја која и даље доминира модерном уметношћу. Њена усмереност ка социјално-политичком ангажману је друга заједничка карактеристика модерне уметности овог историјског периода. И даље је у центру пажње проблематизовање положаја уметности у друштву, као и њених карактеристика и функција које врши унутар културног система. Трећа заједничка особеност свих уметничких подухвата у другој половини прошлог века, узимајући у обзир интенције и садржаје дела је изражено осећање деперсонализације и 
отуђења уметника, човека као фикционалног јунака дела, односно стварног човека унутар дате историјске епохе.

Такође се може приметити да је неоавангардна уметност у срж својих дела уградила политички ангажман. ${ }^{6}$ Модернистичко слављење рационализма и прогреса се полако напушта у корист контингентних и арбитрарних промишљања. Друштво у коме живи, свет масовних медија и почетне фазе развоја софистицираних технологија уопште, једном речју основне елементе постиндустријског друштва, уметник доживљава као лавиринт из којег се излаз не може пронаћи само уз помоћ апстрактних идеологија, већ се трага за могућностима уништења тог лавиринта. У највећем броју случајева, како у Европи тако и у САД, језик је виђен истовремено као непријатељ и оруђе борбе. Унутар њега налазе се алати за размонтирање огромних наслага друштвених производа штетних по само друштво.

Разлике се првенствено проналазе унутар сензибилитета за политичко промишљање света. Код европских неоавангарди може се говорити о упадљивом интересовању за политику. Код већине стваралаца присутан је политички дискурс на свим нивоима: од иронијских коментара дневно-политичких активности до претресања филозофско-идеолошких поставки оних политичких концепата који су током века задобили историјску важност. Могло би се тврдити да је овакво њено самоодређење производ двају околности: прво, прихватање марксистичких или анархистичких начела условљено је порицањем традиционалистичких облика политичког активизма, тј. величања прошлости, установа и старих генерација. Ово се односи како на прошлост и старе друштвене установе, тако и на застареле уметничке поступке.

Политичка интонираност европске неоавангарде је базично утопијска. Ово се дугује њеном блискошћу са основним начелима историјских авангарди. На трагу студентске побуне, а пре тога проживљених страхота у Другом светском рату, утопијска усмереност неоавангарде се може тумачити и као ствар рационалног избора. Утопија се у европској неоавангарди може тумачити и

\footnotetext{
${ }^{6}$ Неоавангарда се, како примећује Хуберт ван ден Берг, није образовала само на основу естетских и политичких уверења. Она не улази у комуникацију само са својом публиком, друштвеним и културним институцијама, већ и са природним окружењем. Он каже да се дела Роберта Смитсона, Дениса Оперхајма и Питера Хачинсона, не могу у строгом смислу означити као еколошка, али код њих и њима сличних уметника може се приметити тежња ка еколошкој упитаности вишег степена, иако су неки од њихових пројеката створени у већ култивисаним или изопаченим пејзажима (van den Bergh, 2006: 979-980).

7 Клер Бишоп, полемишући са Николасом Буриом, говори о томе да је излишно износити тезу о релационом односу уметности и публике у данашњем времену, јер су генерације авангардних покрета од почетка XX века до 60-их година овај однос увелико етаблирале. Према њеном мишљењу, треба се питати да ли уметност која је настала током 90-их година, коју Бурио слави, нуди могућност за антагонизам као праве мере демократичности у уметности. Бишоп оцењује да је уметност од тог периода своје постојање засновала прагматично и микротопски, док је уметност авангардних покрета видела као производ утопијског жара чији су циљеви изумевање социјалних и уметничких имагинарија и као таква била и естетски и комуникативно богатија од потоњих ( Види:Bishop, 2004: 52-64).
} 
као конститутивни идентитетски елемент, на основу кога она одређује себе као авангарду. Своје деловање види у строгој повезаности са амбицијом ка реконструкцији друштвених и културних наслага прошлости и садашњности и што је за сваку авангарду још важније, ка антиципацији будућности. Без овог елемента она не би могла бити означена као вид авангардног деловања.

У поређењу са европском, америчка неоавангарда од апстрактног експресионизма, преко поп арта до концептуалне уметности исказује далеко мању амбицију ка политичком ангажману. Ако и постоји, политичност америчке неоавангарде је спорадична и идеолошки неодређена, у најмању руку, без отворене декларисаности. Готово све појаве уметности у ХХ веку у САД настају као производ модернизма. Код неких уметника дело се појављује као недиференцирана мешавина романтичарских елемената XIX века, авангардних пракси с почетка XX века и неоавангардних стремљења која су се у Европи појавила непосредно након Другог светског рата.

Неоавангарда у САД је још увек заокупљена чисто естетичким питањима, па се спољашњи свет у делу појављује на импресионистички начин, као подлога за обликовање дела. Она још није досегла степен производње фикционалних структура. Тек са концептуалном уметношћу естетско се почиње претварати у политичко. Сукоб апстрактног експресионизма и поп арта око представљања је још више допринео суспензији политичког ангажмана. Могуће је претпоставити и још један разлог за њену аполитичност. Ако је тачна констатација да је поп арт изложио властиту опседнутост делима масовне културе, а концептуална уметност капацитетом уметности да производи идеје, онда се може тврдити да се политичност и не може појавити као друштвена потреба, jep се, у социолошком смислу, политика налази изван хоризонта свести ствараоца. Његово стваралаштво се не подвргава директно утицају политичких структура ${ }^{8}$, већ се оно налази у блиском додиру са новим техничким изумима, новим обрасцима делања и мишљења. Уметник је увидео да је нови тип друштва произвео нове потребе: за обожавањем славних личности, за поседовањем све већег броја материјалних предмета и сл. У америчкој неоавангарди уметник се задовољава тиме да уметнички изоловани предмет који је код маса већ постао фетиш, изложи само као индиферентни коментар, не узимајући у обзир шири друштвени и политички контекст, бар не у мери у којој би се политичко значење код реципијента формирало као основно значење. Код анализе америчке неоавангарде треба у обзир узети још једну околност: неоавангардни уметник у САД могуће политику свесно придружује владавини спектакла, те се она у делу појављује само као недиференцирани објекат тог спектакла.

Неоавангарда се у САД у највећој мери појављује лишена утопијских импликација, што посебно важи за дела поп арта. Овде се о утопији никако не може говорити као индукованој из садржаја дела, већ можда једино унутар

\footnotetext{
${ }^{8}$ Међутим треба увек имати у виду да су рок групе, нарочито оне које су својим аудитивним и визуелним елементима биле блиске авангардном изразу, као што су Дорси, заступале директан политички ангажман.
} 
деловања његове колективне рецепције, у комуникацији са масовним медијима. Одсуство утопије из стваралаштва америчке неоавангарде може се објаснити управо њеном аполитичношћу. Уметнички подухвати овде се темеље не на распакивању историјских и идеолошких склопова, већ на покушају иронијске имитације свакодневице. У том смислу се уметнички подухвати могу посматрати као прагматични, утилитарни. Они треба да допринесу неком конкретном, употребљивом сазнању или пракси. Отуда се и интерес за утопије и филозофске апстракције исказује на начин као да омета ову прагматичну усмереност уметности. Могуће је говорити и о томе да политика у европском стваралаштву има своје дуго историјско трајање и утемељење, које је и колевка утопијских идеја - од Мора (More), до Маркса (Marx), док се млада америчка култура образовала у духу етике рада, а све снажнија средња класа негује вредности компетиције и друштвеног успона. На основу свега може се поставити питање зашто уопште поп арт и концептуалну уметност називамо авангардом? Чињеница да се америчке уметничке праксе нису определиле за директан политички говор, па тиме ни за утопијске пројекције, не значи да је она одустала од антиципаторних амбиција. Иако је сама себе лишила политичког дискурса, америчка неоавангарда, разлажући предмете из света свакидашњице тендира објашњењу будућности као садашњости, тј. указује на то да је будућност, заједно са радио апаратима, телевизорима и нешто касније рачунарима, већ стигла. Испоставља се да авангардни уметник у САД има идеју о вечном стајању времена, антиципирајући овим ставом неке постмодернистичке концепције.

То би заправо могло да значи и још једну разлику између европске и америчке неоавангарде. Европска неоавангарда своје стваралаштво, комуникацију са публиком и читав арсенал стилских решења прилагођава свесном одређењу себе као авангарде, тј. политичком и утопијском деловању. Овде је стваралаштво потпуно у функцији политичког ангажмана, тј. настојања да се свет радикално промени. Ово, ипак, не искључује питања стила и других формалних елемената нити иде на њихову штету. Напротив, на њима се инсистира. Револуција у уметности је за њих део глобалног револуционарног процеса. Политика се не појављује као демијург уметности, већ уметност користи политику: за револуционисање друштва помоћу уметности, али и за револуционисање саме уметности.

С друге стране, утопијски моменат у америчкој неоавангарди није очигледан и у великом броју случајева је чак потпуно одсутан, ако се мисли на његово непосредно појављивање у делу. Он је присутан више на посредан начин и то пре као дистопија. До ње је могуће допрети не на основу појединачних дела Ворхола или Кошута, већ синтетичким захватом укупног стваралаштва америчке неоавангарде, која у својој суштини за предмет узима баналност модерног, технички опремљеног света, који ужива у нагомиланим кич творевинама. Одсуство политике и посебно утопије као трансендирајућег, овде је видљиво и у помирљивости уметника са актуелном и уметнички доживљеном стварношћу. Уметник не може да мења стварност. Он може о њој путем дела да сведочи или утиче на неке њене сегменте, али је стварност као тоталитет неухватљива и недостижна за оскудну друштвену моћ поверену институцији уметности. 
Масовна култура и специјално супкултуре имале су снажан утицај како на европску тако и на америчку неоавангарду. То такође важи и за неоавангардну публику. У добу осцилација укуса, како би то рекао Ђило Дорфлес (Dorfles), публика неоавангарде увиђа да су дела популарне културе задобила важно место у уметничком стваралаштву. Популарна култура постаје референтна тачка око које се одиграва читав стваралачко-рецептивни процес неоавангарде. Када је у питању неоавангардна публика уопште, можемо говорити о јединственом уметничком афинитету, који се темељи на разумевању авангардне уметничке праксе и настајуће постмодерне филозофије. Ипак, упутније је говорити о неоавангардним публикама, па се, у том смислу, мора подвући разлика између оног њеног дела који нагиње делима поп арта и, с друге стране, публике наклоњеније италијанској неоавангардној књижевности, новом роману, или концептуалној уметности.

\section{Закључак}

У складу са изводом из разлика о стваралаштву европске и америчке неоавангарде, може се рећи да се формирање публике једног односно другог културолошког круга одвија на истим принципима. Неоавангардна публика у Европи би била политичнија у ставовима о друштву и култури, радикалнија и уопште више заинтересована за питања историје уметности и књижевности, те за промишљање политичке улоге уметности у савременом друштву. Америчка неоавангардна публика, према овом теоријском моделу, неговала би склоности ка естетизовању стварности, са примесама кемпа и са још већим утицајем дела масовне културе на њено разумевање света. Ова публика би била нешто либералнија у њеном ставу према делима популарне културе у односу на европску публику, али и овде може бити говора о критичкој дистанци. Такође би се могло претпоставити да је утицај супкултура при рецепцији знатно већи, тј. могуће је да се нека дела неоавангардне уметности у САД и прихватају на основу претходно створених рецептивних пракси произашлим из деловања музичких супкултура које кореспондирају авангардној поетици. Тако се веза масовна култура-супкултура-неоавангарда, на примеру разматрања неовангардне публике у САД може оценити као чвршћа у односу на њен европски пандан. Поједностављено, иако са иронијским одмаком, неоавангардна публика у САД би на стваралаштво, као и на свет гледала очима чисте забаве у којој се испитују својства елемената културе. Европска неовангардна публика би била више заинтересована за темељнију реконструкцију културних наслага. На присуство мотива из области популарне културе у неоавангардним делима би се гледало као на социолошку датост, са умереном дозом симпатија, али би рецепција била усмерена на комуникацију са дубљим стваралачким структурама неоавангардне уметности.

Културолошки дефинисани појмови америчке и европске неоавангарде имају функцију изградње теоријско-аналитичких конструкција на основу којих 
би се могле сагледати опште стваралачко-рецептивне карактеристике једног односно другог културног простора у другој половини прошлог века. У стварности се тешко може говорити о оштрим дистинкцијама међу неоавангардним покретима. Пре би се могло говорити о њиховим међусобним утицајима и испреплетености великог броја стваралачких пракси.

\section{Литература}

Bishop, C. (2004) „Antagonism and Relational Aesthetics“ October. 110. pp. 51-79.

Bonito Oliva, A./Karlo Argan Đ. (2006). Moderna umetnost III 1770-1970-2000. Beograd: Clio.

Božilović, N. (2009) Izvan glavnoga toka: Sociologija muzičkih potkultura. Niš: Niški kulturni centar.

Bürger, P. (2011) „Avant and Neo-Avant-Garde: An Attempt to Answer Certain Critics of Theory of Avant-garde. New Literay History. pp. 595-715.

Van den Berg, H. (2006) „Towards a 'Reconciliation of a man and nautre'. Nature and Ecology in the Aesthetic Avant-Garde Twentieth Century“ in: Neo-avantgarde: Crtitical Studies. Edited by David Hopkins. Amsterdam-New York: Radopi. pp. 371389.

Vilson, E. (1995) Istorija mode. Beograd: Art Press.

Dedić, N. (2009) Utopijski prostori umetnosti i teorije posle 1960. Beograd: Atoča/ Standard 2.

Kise, F. (2015) French theory: Fuko, Derida, Delez \& Co i preobražaj intelektualnog života u SAD. Loznica/Beograd: Karpos/Zuhra.

Krauss, R. (1979) „Grids“. October. Vol. 9. pp. 50-64.

Leksikon avangarde (2013) prir. Hubert van den Berg i Valter Fenders. Beograd: Mecler/ Službeni glasnik.

Risman, D., Glejzer, N., Deni, R. (2006) Usamqena gomila: Studija o promeni američkog karaktera. Novi Sad: Mediterran Publishing.

Raunig, G. (2007) Art and Revolution: Transversal Activism in the Long Twentieth Century. https://selforganizedseminar.files.wordpress.com

Roszak, T. (1978) Kontrakultura: razmatranja o tehnokratskom društvu i njegovoj mladenačkoj opoziciji. Zagreb: Naprijed.

Саболчи, М. (1997) Авангарда и неоавангарда. Београд: Народна књига.

Hebdiž, D., Majler, N., Brejk, M., Holms, Dž., Hol, S. (2002) Subkulture. Beograd: Art Press.

Honef, K. (2008) Pop art. Beograd: IPS Media (Nemačka).

Šuvaković, M. (1995) Postmoderna. Beograd: Narodna knjiga. 


\section{COMPARATIVE RESEARCH OF NEO-VANGUARD MOVEMENTS IN EUROPE AND USA}

Abstract: The subject of research is neo-vanguard movements in Europe and United States. The aim of research is to find out similarities and differences between European and neo-avant-garde in the United States. Neo-avant-garde is called a set of various artistic endeavors that emerge after the Second World War. It is the created on the European soil as a form understanding and criticism of society. Among neovanguard artistic practices are those in North America. The term is affirming in Italy in the 1960s where the greatest development of the neo-avant-garde has occurred. Its orientation towards social-political engagement is a common feature in this period. Characteristic of all endeavors of neo-avant-garde is expressively feeling of depersonalization. Differences are primarily observed within policy sensitivity. In comparison with European, American neo-avant-garde seeks less ambition towards political engagement. Article shows that both European and neo-avant-garde in the United States have been affected by subcultural and counter-cultural movements.

Key words: Vanguard movements, Neo-avant-garde, Counter-culture, Europe, USA. 
